\title{
A comparison of the effect of soybeans roasted at different temperatures versus calcium salts of fatty acids on performance and milk fatty acid composition of mid-lactation Holstein cows
}

\author{
H. Rafiee-Yarandi, ${ }^{*}$ G. R. Ghorbani, ${ }^{*}$ M. Alikhani, ${ }^{*}$ A. Sadeghi-Sefidmazgi, ${ }^{*}$ and J. K. Drackleyt ${ }^{1}$ \\ *Department of Animal Sciences, College of Agriculture, Isfahan University of Technology, Isfahan 84156-83111, Iran \\ †Department of Animal Sciences, University of Illinois, Urbana 61801
}

\begin{abstract}
To evaluate the effect of soybeans roasted at different temperatures on milk yield and milk fatty acid composition, 8 (4 multiparous and 4 primiparous) mid-lactation Holstein cows $(42.9 \pm 3 \mathrm{~kg} / \mathrm{d}$ of milk) were assigned to a replicated $4 \times 4$ Latin square design. The control diet $(\mathrm{CON})$ contained lignosulfonate-treated soybean meal (as a source of rumen-undegradable protein) and calcium salts of fatty acids (Ca-FA, as a source of energy). Diets 2,3 , and 4 contained ground soybeans roasted at 115,130 , or $145^{\circ} \mathrm{C}$, respectively (as the source of protein and energy). Dry matter intake (DMI) tended to be greater for CON compared with the roasted soybean diets (24.6 vs. $23.3 \mathrm{~kg} / \mathrm{d})$. Apparent total-tract digestibilities of dry matter, organic matter, and crude protein were not different among the treatments. Actual and $3.5 \%$ fat-corrected milk yield were greater for $\mathrm{CON}$ than for the roasted soybean diets. Milk fat was higher for soybeans roasted at $130^{\circ} \mathrm{C}$ than for those roasted at either 115 or $145^{\circ} \mathrm{C}$. No differences were observed between the CON and the roasted soybean diets, or among roasting temperatures, on feed efficiency and nitrogen concentrations in rumen, milk, and plasma. Milk from cows fed roasted soybeans had more long-chain fatty acids and fewer medium-chain fatty acids than milk from cows fed Ca-FA. Compared with milk from cows fed the CON diet, total milk fat contents of conjugated linoleic acid, cis-9, trans-11 conjugated linoleic acid, cisC18:2, cis-C18:3, and C22:0 were higher for cows fed the roasted soybean diets. Polyunsaturated fatty acids and total unsaturated fatty acids were greater in milk from cows fed roasted soybean diets than in milk from cows fed CON. Concentrations of C16:0 and saturated fatty acids in milk fat were greater for CON than for the roasted soybean diets. Cows fed roasted soybean diets had lower atherogenic and thrombogenic indices than
\end{abstract}

Received October 20, 2015.

Accepted February 23, 2016.

${ }^{1}$ Corresponding author: drackley@illinois.edu cows fed CON. Milk fatty acid composition did not differ among different roasting temperatures. In summary, results showed that cows fed CON had higher DMI and milk yield than cows fed roasted soybean diets. Among different roasting temperatures (115, 130, and $145^{\circ} \mathrm{C}$ ), soybeans roasted at $115^{\circ} \mathrm{C}$ led to higher milk production and lower DMI. Cows fed roasted soybeans, regardless of the roasting temperature, had more unsaturated fatty acids in milk. Using roasted soybeans in dairy cow rations could, therefore, improve the health indices of milk for human nutrition.

Key words: roasted soybeans, calcium salts of fatty acids, milk fatty acids

\section{INTRODUCTION}

Fats and oils have been included in diets for dairy cows for many years, principally to increase the energy density of the diet in an attempt to increase energy intake by high-yielding cows. More recently, lipids were included in the diet of lactating dairy cows in an attempt to alter the fatty acid composition of milk fat and improve its nutritional properties. Conjugated linoleic acid is a fatty acid that naturally occurs in foods derived from ruminants, with cis-9,trans-11-CLA (rumenic acid) the predominant isomer of CLA (more than $82 \%$ of total CLA) in dairy products (Dilzer and Yeonhwa, 2012). Conjugated linoleic acid could be beneficial for human health because of its anticarcinogenic properties (Dilzer and Yeonhwa, 2012). For this reason, increasing the CLA content of milk may enhance the perceived healthfulness of milk and milk products, and increase the consumption of CLA by humans. Vegetable oils in dairy cow diets generally increase the CLA concentration of milk (Dhiman et al., 2000). However, vegetable oils may alter populations of fiber-digesting microbes in the rumen and reduce fat content in milk, and therefore, they are not usually used in dairy diets (Jenkins and Harvatine, 2014).

The use of processed oilseeds is one possible solution to increase CLA without adversely affecting the 
rumen microbes. Whole soybeans are a good source of protein and energy for dairy cows. Processed soybeans have been generally considered as a source of protein, and several heat-treating processes have been used to increase proportions of RUP in the seeds (Faldet and Satter, 1991; Faldet et al., 1992; McNiven et al., 1994). Roasting and extruding are the most common heat processing techniques applied to whole soybean seeds. Faldet and Satter (1991) reported that cows fed roasted soybeans had higher milk production than those fed extruded soybeans. During the extrusion process, oil vesicles in the soybean seed are damaged. By making the oil more readily available in the rumen, extrusion may then decrease fat content of milk in the same way as feeding free oil (Faldet and Satter, 1991). Although several studies have determined the effects of extruded soybeans on milk fatty acid composition (Chouinard et al., 1997b; Solomon et al., 2000), few studies are available on the effect of roasted soybeans on milk fatty acid profile (Mohamed et al., 1988; Tice et al., 1994).

Different roasting temperatures have been applied to increase the proportions of RUP when roasted soybeans are fed to lactating cows (Faldet et al., 1992). However, little consideration has been given to the effect of different roasting temperatures on the fatty acid composition of milk fat. Application of heat during roasting might protect fat from microbial biohydrogenation in the rumen (Abdi et al., 2013), by denaturing the protein matrix surrounding the fat droplets (Khorasani et al., 1992) or by binding peroxides of UFA with amino groups of proteins (Abel-Caines et al., 1998), and thus increasing the concentrations of PUFA in milk. Another common source of fat in dairy ration is calcium salts of FA (Ca-FA). Few studies are available comparing CaFA and roasted soybeans on cow performance and milk fatty acid composition, and we are aware of no studies considering the effect of roasting temperature on milk fatty acid profile.

The objectives of this study were (1) to determine whether roasting soybeans, as well as roasting temperature, could affect the fatty acid composition of milk fat, (2) to compare effects of roasted soybeans with those of Ca-FA on CLA content and fatty acid profile of milk, and (3) to investigate the effect of soybeans roasted at different temperatures and compare their effect with that of Ca-FA on the performance of dairy cows.

\section{MATERIALS AND METHODS}

The study was conducted under protocols previously approved by the Animal Care and Use Committee of the Iranian Council of Animal Care (1995). The experiment was conducted at the Farm Animal Research and
Teaching Unit of Isfahan University of Technology in the region of Lavark near Najaf-Abad, Iran.

\section{Experimental Design, Cow Management, and Treatments}

Eight lactating Holstein cows were used in a duplicated $4 \times 4$ Latin square design consisting of 21-d periods, of which $16 \mathrm{~d}$ were used as the adaptation period followed by $5 \mathrm{~d}$ for sampling and data collection. Four multiparous (third parity, $90 \pm 18$ DIM, BW $=631 \pm$ $33 \mathrm{~kg}$, milk production $=44.2 \pm 3.9 \mathrm{~kg} / \mathrm{d}$; mean $\pm \mathrm{SE}$ ) and 4 primiparous $(95 \pm 12 \mathrm{DIM}, \mathrm{BW}=548 \pm 32 \mathrm{~kg}$, milk production $=41.8 \pm 1.8 \mathrm{~kg} / \mathrm{d}$; mean $\pm \mathrm{SE}$ ) Holstein cows were used in the experiment. Cows within square were randomly assigned to dietary sequences arranged to minimize carryover effects. Throughout the experiment, each cow was housed in a box stall $(4 \times 4 \mathrm{~m})$ in a roofed barn with open sides. Each box stall was bedded with clean wood shavings refreshed twice daily. Each stall had a concrete feed bunk and automatic water troughs.

Dietary treatments included treatment 1, a TMR containing Ca-FA and lignosulfonate-treated soybean meal (SBM) as a control diet $(\mathbf{C O N})$; treatment 2, a TMR containing soybeans roasted at $115^{\circ} \mathrm{C}(\mathbf{R S 1 1 5})$; treatment 3, a TMR containing soybeans roasted at $130^{\circ} \mathrm{C}$ (RS130); and treatment 4, a TMR containing soybeans roasted at $145^{\circ} \mathrm{C}$ (RS145). Ingredient composition and chemical composition of the diets are presented in Tables 1 and 2. The forage to concentrate ratio was 40:60 on a DM basis, with corn silage and chopped alfalfa hay as the forage components. Prior to feeding, alfalfa hay was chopped with a theoretical length of $30 \mathrm{~mm}$ using a harvesting machine with screen size regulator (Golchin Trasher Hay Co., Isfahan, Iran). Corn silage was used from the silo and sampled on a weekly basis for DM content, and its inclusion in the TMR was adjusted accordingly. Dry matter content of corn silage samples was determined after drying at $60^{\circ} \mathrm{C}$ in a forced-air oven for $48 \mathrm{~h}$ (Faldet et al., 1992). Barley and corn grains were ground using a hammer mill with 3-mm screen size (model 5543 GEN, Isfahan Dasht, Isfahan, Iran). In diets 2,3 , and 4 , soybeans roasted at 115,130 , or $145^{\circ} \mathrm{C}$ were included at the expense of SBM, lignosulfonate-treated SBM, and Ca-FA used in diet 1. Soybeans were roasted for $10 \mathrm{~min}$ and immediately cooled after roasting by horizontal cooler (Bisotun Co., Isfahan, Iran). The roasted soybeans were ground by passing them through a hammer mill (model 55, Gehl Company, West Bend, WI) with a 9-mm screen size. The geometric mean particle size of ground soybeans was then calculated using the dry-sieving technique 
Table 1. Ingredients of experimental diets

\begin{tabular}{|c|c|c|c|c|}
\hline \multirow[b]{2}{*}{ Ingredient, $\%$ of $\mathrm{DM}$} & \multicolumn{4}{|c|}{ Diet $^{1}$} \\
\hline & $\mathrm{CON}$ & RS115 & RS130 & RS145 \\
\hline Alfalfa hay & 19.12 & 19.15 & 19.15 & 19.15 \\
\hline Corn silage & 21.16 & 21.18 & 21.18 & 21.18 \\
\hline Ground barley grain & 17.09 & 17.11 & 17.11 & 17.11 \\
\hline Ground corn grain & 21.56 & 21.59 & 21.59 & 21.59 \\
\hline Ground roasted soybeans & 0 & 17.92 & 17.92 & 17.92 \\
\hline Soybean meal, $44 \% \mathrm{CP}$ & 2.44 & 0 & 0 & 0 \\
\hline Lignosulfonate treated soybean meal ${ }^{2}$ & 12.21 & 0 & 0 & 0 \\
\hline Calcium salts of fatty acids ${ }^{3}$ & 3.78 & 0 & 0 & 0 \\
\hline Sodium bicarbonate & 0.77 & 0.77 & 0.77 & 0.77 \\
\hline Magnesium oxide & 0.33 & 0.33 & 0.33 & 0.33 \\
\hline Calcium carbonate & 0 & 0.41 & 0.41 & 0.41 \\
\hline Dicalcium phosphate & 0.41 & 0.41 & 0.41 & 0.41 \\
\hline White salt & 0.11 & 0.11 & 0.11 & 0.11 \\
\hline Mineral and vitamin premix ${ }^{4}$ & 0.98 & 0.98 & 0.98 & 0.98 \\
\hline \multicolumn{5}{|c|}{$\begin{array}{l}{ }^{1} \mathrm{CON}=\text { calcium salts of fatty acids; } \mathrm{RS} 115=\text { soybean roasted at } 115^{\circ} \mathrm{C} ; \mathrm{RS} 130=\text { soybean roasted at } 130^{\circ} \mathrm{C} \\
\mathrm{RS} 145=\text { soybean roasted at } 145^{\circ} \mathrm{C} .\end{array}$} \\
\hline \multicolumn{5}{|l|}{${ }^{2}$ Sanadam Pars Co., Tehran, Iran. } \\
\hline \multicolumn{5}{|c|}{$\begin{array}{l}{ }^{3} \text { Nutracor, Wawasan, Malaysia. Composition: ash } 13 \% \text {, moisture } 3 \% \text {, calcium } 9 \% \text {, crude fat } 85 \%(\mathrm{C} 12: 0,0.2 \% \\
\text { C14:0, 1.2\%; C16:0, 47\%; C18:0, } 5 \% \text {; C18:1, 38\%; C18:2, 8\%). }\end{array}$} \\
\hline \multicolumn{5}{|c|}{$\begin{array}{l}{ }^{4} \text { Composition: } 195 \mathrm{~g} / \mathrm{kg} \text { of Ca, } 21 \mathrm{~g} / \mathrm{kg} \text { of } \mathrm{Mg}, 2.2 \mathrm{~g} / \mathrm{kg} \text { of Mn, } 0.3 \mathrm{~g} / \mathrm{kg} \text { of } \mathrm{Zn}, 0.3 \mathrm{~g} / \mathrm{kg} \text { of Cu, } 0.12 \mathrm{~g} / \mathrm{kg} \text { of I } \\
0.1 \mathrm{~g} / \mathrm{kg} \text { of Co, } 600,000 \mathrm{IU} / \mathrm{kg} \text { of vitamin A, 200,000 IU } / \mathrm{kg} \text { of vitamin D, and } 0.2 \mathrm{~g} / \mathrm{kg} \text { of vitamin E, } 0.025 \mathrm{~g} \text {, } \\
\mathrm{kg} \text { of Se. }\end{array}$} \\
\hline
\end{tabular}

(ASAE, 1995). The average geometric mean particle size was $1.15 \mathrm{~mm}$ for the ground soybeans. The lignosulfonate-treated SBM was commercially produced by combining SBM with lignosulfonate liquor (containing xylose) in the presence of heat (Sanadam Pars Co., Tehran, Iran). Diets were formulated to meet or exceed the nutrient allowances specified by the Cornell Net Carbohydrate and Protein System (version 5.0) for cows that produced $45 \mathrm{~kg} / \mathrm{d}$ of milk (3.2\% fat and $3.0 \%$ protein), consumed $24.1 \mathrm{~kg} / \mathrm{d}$ of DM, were $635 \mathrm{~kg}$ of BW, and were 100 DIM. Individual DMI of cows was estimated during the adaptation period. During the experimental period, the TMR was offered for ad libitum intake, allowing for 5 to $10 \%$ orts daily. The total daily amount of TMR for individual cows was offered in 2 portions daily at 1000 and $1700 \mathrm{~h}$.

\section{Sampling, Measurements, and Analyses}

Feed offered and orts were measured and sampled daily for each cow during the collection period and DMI was determined daily for each cow. Samples were refrig-

Table 2. Chemical composition of total mixed diets

\begin{tabular}{|c|c|c|c|c|}
\hline \multirow[b]{2}{*}{ Item $^{2}$} & \multicolumn{4}{|c|}{$\operatorname{Diet}^{1}$} \\
\hline & $\mathrm{CON}$ & RS115 & RS130 & RS145 \\
\hline $\mathrm{DM}, \%$ & 56.34 & 56.52 & 57.16 & 57.31 \\
\hline $\mathrm{OM}, \%$ of $\mathrm{DM}$ & 92.53 & 92.72 & 92.64 & 92.73 \\
\hline Ether extract, \% of DM & 4.17 & 4.37 & 4.25 & 4.70 \\
\hline $\mathrm{NDF}, \%$ of $\mathrm{DM}$ & 30.93 & 34.72 & 34.67 & 35.82 \\
\hline $\mathrm{ADF}, \%$ of $\mathrm{DM}$ & 16.57 & 17.04 & 17.38 & 17.46 \\
\hline $\mathrm{NE}_{\mathrm{L}},{ }^{3} \mathrm{Mcal} / \mathrm{kg}$ of DM & 1.65 & 1.65 & 1.65 & 1.65 \\
\hline $\mathrm{CP}, \%$ of $\mathrm{DM}$ & 14.93 & 15.11 & 15.15 & 15.10 \\
\hline $\mathrm{RDP}, \% \mathrm{CP}$ & 43.51 & 47.34 & 45.85 & 46.99 \\
\hline RUP, \% CP & 56.48 & 52.66 & 54.14 & 53.01 \\
\hline Digestible RUP, $\%$ of RUP & 78.37 & 69.71 & 59.78 & 66.65 \\
\hline Neutral detergent insoluble $\mathrm{CP}, \%$ of total CP & 14.93 & 16.41 & 24.98 & 26.39 \\
\hline Acid detergent insoluble $\mathrm{CP}, \%$ of total $\mathrm{CP}$ & 7.23 & 10.29 & 13.86 & 13.37 \\
\hline
\end{tabular}


erated until the end of the collection period, at which time they were combined by cow and sampled. This sub-sample was frozen and stored at $-20^{\circ} \mathrm{C}$ pending analysis. Dry matter content of feed and orts samples was determined after drying at $60^{\circ} \mathrm{C}$ in a forced-air oven for $48 \mathrm{~h}$ (Faldet et al., 1992), and samples were ground to pass through a 1-mm screen (Wiley mill, Arthur H. Thomas). The ground samples were analyzed for NDF with a heat stable $\alpha$-amylase $(100 \mu \mathrm{L} /$ sample $)$ and ADF according to Van Soest et al. (1991). Contents of DM, ash, CP, and ether extract were analyzed according to AOAC International (2002). Lipids in soybean samples were removed by chloroform-methanol extraction before NDF and ADF determination to facilitate the complete recovery of fiber fractions (Aldrich et al., 1995). Rumen degradable protein, RUP, and the digestibility of RUP were determined according to a 3 -step procedure using the in situ residues after $16 \mathrm{~h}$ of ruminal incubation (6 replicates; Calsamiglia and Stern, 1995). Additional samples of the NDF and ADF components were further processed to determine acid and neutral detergent insoluble CP (ADICP and NDICP; Licitra et al., 1996).

Fecal grab samples were obtained from each cow for 4 consecutive days at 12-h intervals (Cooke et al., 2008). Sampling time was advanced by $2 \mathrm{~h}$ each day so that samples were collected at 0500, 0700, 0900, 1100, 1700, 1900,2100 , and $2300 \mathrm{~h}$. The samples were composited by cow and kept frozen at $-20^{\circ} \mathrm{C}$ until analyzed. Samples were dried in a forced-air oven at $60^{\circ} \mathrm{C}$ for 72 $\mathrm{h}$, ground to pass through a 1-mm screen, and analyzed for DM, ash, ADF, NDF, and CP, as described for feeds and orts. Apparent total-tract digestibilities of nutrients were obtained using the acid-insoluble ash internal marker method (Van Keulen and Young, 1977).

\section{Milk Production and Composition}

Cows were milked 3 times daily at 0100, 0900, and $1700 \mathrm{~h}$. Milk yields were recorded and averaged to determine the mean milk yield for the entire period. Milk was sampled at each milking during the 5-d sampling period. Milk samples were preserved with potassium dichromate and stored at $4^{\circ} \mathrm{C}$ pending analysis. Milk samples were analyzed for fat, total protein, and TS by Milkoscan (134 BN Foss Electric, Hillerød, Denmark; AOAC International, 2002). The MUN content was determined by enzymatic assay (Wilson et al., 1998). Yields of milk components were calculated by multiplying the concentration of the component by the yield of milk at each milking time on days during which the sample was taken.

Yields of 3.5\% FCM, fat- and protein-corrected milk (FPCM), and ECM were calculated as follows:
$3.5 \% \mathrm{FCM}=0.4324$ (kilograms of milk)

+16.216 (kilograms of fat),

$$
\begin{gathered}
\mathrm{FPCM}=(0.337+0.116 \times \text { fat } \%+0.06 \times \text { protein } \%) \\
\times \text { milk yield }(\mathrm{kg} / \mathrm{d}), \text { and }
\end{gathered}
$$

$$
\begin{gathered}
\operatorname{ECM}(\mathrm{kg} / \mathrm{d})=[(41.63 \times \text { fat } \%+24.13 \times \operatorname{protein} \% \\
+21.60 \times \text { lactose } \%) \times \text { milk yield, } \mathrm{kg} / \mathrm{d}] /(1,296)
\end{gathered}
$$

Feed efficiency was calculated by dividing the daily actual milk or $3.5 \%$ FCM production $(\mathrm{kg} / \mathrm{d})$ by DMI $(\mathrm{kg} / \mathrm{d})$.

On d 18 of each period, additional aliquots of milk from 3 consecutive milkings were obtained and stored at $-20^{\circ} \mathrm{C}$ until analysis for milk fatty acid composition. These samples were composited based on proportion to milk yield at each milking time. Fatty acids in milk were directly methylated with $1 \mathrm{~mL}$ of $2 \mathrm{~N} \mathrm{NaOCH}$ at room temperature for $20 \mathrm{~min}$, followed by $1 \mathrm{~mL}$ of $14 \%$ boron trifluoride in methanol at room temperature for 20 min. Fatty acid methyl esters were recovered in $1 \mathrm{~mL}$ of hexane (Loor et al., 2005). The fatty acid concentration was determined by gas chromatograph (DANI1000, Milan, Italy) equipped with a flame ionization detector (Ciola Gregori Ltda., Sao Paulo, Brazil). Methyl esters were separated using a $120 \mathrm{~m} \times 0.25 \mathrm{~mm}$ i.d. column with $0.25 \mathrm{~mm}$ film thickness (Econo-Cap EC-1000, Alltech, Deerfield, IL). Procedures for GLC analyses were as described in Loor et al. (2005).

\section{Ruminal Fermentation and Blood Metabolites}

On $21 \mathrm{~d}$ of each period, ruminal fluid samples were collected from each cow, approximately 3 to $4 \mathrm{~h}$ after the morning feeding, using a stomach tube connected to a vacuum pump. The first $50 \mathrm{~mL}$ of the aspirated rumen fluid were discarded to minimize saliva contamination. Then, ruminal liquor samples were strained through 2 layers of cheesecloth. A sub-sample $(15 \mathrm{~mL})$ of strained ruminal fluid was acidified with $3 \mathrm{~mL}$ of $50 \% \mathrm{H}_{2} \mathrm{SO}_{4}$ and frozen at $-20^{\circ} \mathrm{C}$ for later analysis of $\mathrm{NH}_{3}$ (Knapp et al., 1991). Another sub-sample ( $15 \mathrm{~mL}$ ) of strained ruminal fluid was diluted with $3 \mathrm{~mL}$ of $25 \%$ metaphosphoric acid for VFA analysis (Khorasani et al., 1992) and frozen until analysis. Rumen fluid samples for $\mathrm{NH}_{3}$ analysis were thawed and centrifuged at 30,000 $\times g$ for $20 \mathrm{~min}$ at $4^{\circ} \mathrm{C}$; the supernatant was removed and analyzed for $\mathrm{NH}_{3}$ by the colorimetric phenol-hypochlorite method (Broderick and Kang, 1980). Rumen fluid samples for VFA analysis were thawed and centrifuged at 10,000 $\times g$ at $4^{\circ} \mathrm{C}$ for 20 min and analyzed for VFA using gas chromatography $(0.25 \times 0.32,0.3 \mu \mathrm{m}$ i.d. fused silica 
capillary, model no. CP-9002 Vulcanusweg 259 a.m., Chrompack, Delft, the Netherlands), as described by Bal et al. (2000).

Blood samples from the coccygeal vessel were collected in evacuated tubes with anticoagulant (EDTA) on $\mathrm{d} 20$ at approximately $4 \mathrm{~h}$ postfeeding. Samples were centrifuged for $15 \mathrm{~min}$ at $3,000 \times g$ at $4^{\circ} \mathrm{C}$, and plasma was harvested and frozen at $-20^{\circ} \mathrm{C}$ until analysis (Bahrami-Yekdangi et al., 2014). Concentrations of glucose (glucose oxidase-phenol 4-aminoantipyrine peroxidase method, kit number 1500017), triglyceride (glycerol-3-phosphate oxidase-phenol 4-aminoantipyrine peroxidase method, kit number 1500032), total protein (Biuret method, kit number 1500028), albumin (bromocresol green method, kit number 1500001), urea N (Berthelot method, kit number 1400030), cholesterol (cholesterol oxidase-phenol 4-aminoantipyrine peroxidase method, kit number 1500010), and uric acid (enzymatic colorimetric uricase method, kit number 1400031) were measured using commercial kits (Pars Azmoon Co., Tehran, Iran) according to the manufacturer's instructions. Concentrations of BHB in plasma samples were determined with a commercial colorimetric kit (kit number RB1007, Randox Laboratories Ltd., Ardmore, UK). Globulin concentrations were obtained by deducting albumin from total protein.

\section{Experimental Design and Statistical Analysis}

Data were analyzed as a duplicated $4 \times 4$ Latin square design using PROC MIXED of SAS (SAS Institute Inc., Cary, NC). The model included fixed effects of square, period, and treatment. Cow within square was included in the RANDOM statement. The original model included square $\times$ treatment and square $\times$ period interactions, but these interactions were not significant for any variable, and they were pooled with the error term in the final model. Days in milk of cows was used as a covariate adjustment, but because it was not significant it was removed from the final model. Normality of distribution and homogeneity of variance for the residuals were tested using PROC UNIVARIATE (SAS Institute Inc., 2002). Orthogonal contrasts were used to evaluate the differences between Ca-FA and roasted soybeans, as well as the linear or quadratic effects of increasing roasting temperatures. Values are reported as least squares means. Data taken from the same animal, on different days, were considered as repeated measures, and appropriate variance-covariance matrixes were modeled to account for them. The best-fit covariance structure was first-order autoregressive [AR (1)] based on the lowest Bayesian information criteria. Significance was declared at $P \leq 0.05$, and trends were noted if $0.05<P \leq 0.10$. Pearson correlation coefficients were estimated using the PROC CORR of SAS (SAS Institute Inc., 2002).

\section{RESULTS AND DISCUSSION}

\section{Chemical Composition of Diets and Feed Ingredients}

Chemical composition of total mixed diets is presented in Table 2. The NDF content of the CON diet was lower $(P<0.01)$ than that of roasted soybean diets (30.9 vs. $35.1 \%$ of DM). The greater NDF content of the roasted soybean diets was partly attributable to the fact that the roasted soybeans contained the hulls, in contrast to SBM (NRC, 2001). Also, because the heat used in soybean roasting $\left(115,130\right.$, and $\left.145^{\circ} \mathrm{C}\right)$ was higher than heat applied to lignosulfonate-treated SBM $\left(90^{\circ} \mathrm{C}\right)$, the roasted soybean diets would be expected to have greater NDF content than the CON diet.

The NDF content of the roasted soybean diets tended to increase linearly as soybean roasting temperature increased $(P=0.07)$. The difference of ADF content among diets was not significant $(P=0.16)$. The different response in the ADF and NDF contents with increasing temperature could be attributed to proteins that were less soluble and, probably, some of the heat denatured proteins were recovered in NDF fraction. Therefore, the $\mathrm{N}$ content of NDF was increased by heating, whereas an increase in $\mathrm{ADF}$ would require the Maillard reaction or condensation of protein with carbohydrate to render protein recoverable in the ADF fraction (Moshtaghi Nia and Ingalls, 1992). This change in ADF and NDF content of heat-treated oilseeds has already been reported (Mustafa et al., 1999, 2000).

Many studies have compared diets with oilseeds with those without added fat as a control diet (e.g., Mohamed et al., 1988; Abu-Ghazaleh et al., 2002). It should be noted that in such research, there were large differences between control and treatment diets with regard to $\mathrm{NE}_{\mathrm{L}}$ and fat content, thereby influencing the performance of dairy cows and milk fatty acid composition. On the other hand, in some experiments, the added fat used in the control diet was the same amount as that used in the treatment diets. When using heat treated oilseeds, the level of RUP was higher in the treatment diet, which could affect cow performance (Dhiman et al., 1995, 1999, 2000). Due to these reasons, in the CON diet in our study Ca-FA and lignosulfonatetreated SBM were used to give equivalent lipid, protein, and RUP contents as the treatment diets (Table 2). The RUP content of the diets was formulated to be high so that differences in response to protein degradability would be more likely to be detected. 


\section{Intake and Digestibility}

Intakes of DM and OM (Table 3) were higher for the CON diet than for roasted soybean diets (24.6 vs. 23.3 $\mathrm{kg} / \mathrm{d}$ for DMI, and 22.5 vs. $21.5 \mathrm{~kg} / \mathrm{d}$ for OM intake). In contrast to our results, Ca-FA, compared with roasted soybeans, reduced DMI in lactating cows (Kim et al., 1993; Dhiman et al., 1995), but in steers, intake tended to be lower for the roasted soybean treatment than the Ca-FA treatment (McNiven et al., 2004). Allen (2000) indicated different hypophagic effects of fat supplements differing in fatty acid source, form, and type. The profile of fatty acid reaching the duodenum has different effects on DMI. Greater hypophagic effects as amount of UFA reaching the duodenum increases might be from greater release of cholecystokinin stimulated by UFA compared with SFA. In addition, UFA might be absorbed and oxidized in the liver more quickly, generating reducing equivalents and satiety faster than SFA (Allen, 2000). Previous researchers have reported that DMI was not affected when cows were fed roasted soybeans (Faldet and Satter, 1991; Knapp et al., 1991; Tice et al., 1993) compared with SBM. However, other studies have reported a reduction in DMI as a result of feeding roasted soybeans as compared with SBM or the untreated soybeans (Mohamed et al., 1988; Akbarian et al., 2014).

In the current trial, cows fed RS130 had higher DMI than cows fed RS115 or RS145. Chouinard et al. (1997b) observed a quadratic effect of extruding tem- perature $\left(120,130\right.$, or $\left.140^{\circ} \mathrm{C}\right)$ of soybeans on DMI, in which cows fed soybeans extruded at $130^{\circ} \mathrm{C}$ had lower DMI throughout the experimental period than cows fed other treatments. However, Aldrich et al. (1995) observed no differences in DMI of steers fed soybeans extruded at different temperatures.

Intakes of CP (mean $3.6 \mathrm{~kg} / \mathrm{d}$ ) and ADF (mean 3.9 $\mathrm{kg} / \mathrm{d})$ were not affected by treatments $(P>0.10)$. Because of the higher NDF content in diets containing the roasted soybeans, cows fed roasted soybean diets had greater NDF intake than those fed CON (mean 7.8 vs. $7.2 \mathrm{~kg} / \mathrm{d}$ ), and NDF intake from diets containing roasted soybeans was linearly increased with increased roasting temperature $(P<0.01)$. Similar to our results, Aldrich et al. (1995) reported that steers fed extruded soybeans had higher NDF intake but similar ADF intake compared with those fed raw soybeans, because of the increase in the NDF content of soybean at the time of extruding. Tice et al. (1993) reported that NDF content of soybeans was increased during roasting and cows ate more NDF when diets with roasted soybeans were used, as compared with diets without roasted soybeans.

The total-tract apparent digestibilities of DM (mean $70.8 \%$ ), OM (mean 73.0\%), CP (mean 68.3\%), and ADF (mean $46.5 \%$ ) were not affected by treatments. The mean NDF digestibility for cows fed diets with roasted soybeans was greater $(P=0.05)$ than that for cows fed CON (mean 53.2 vs. 42.5\%). In agreement with our results, Bernard (1990) reported that diets contain-

Table 3. Least squares means for intake and digestibility for cows fed calcium salts of fatty acids or ground whole soybeans roasted at different temperatures

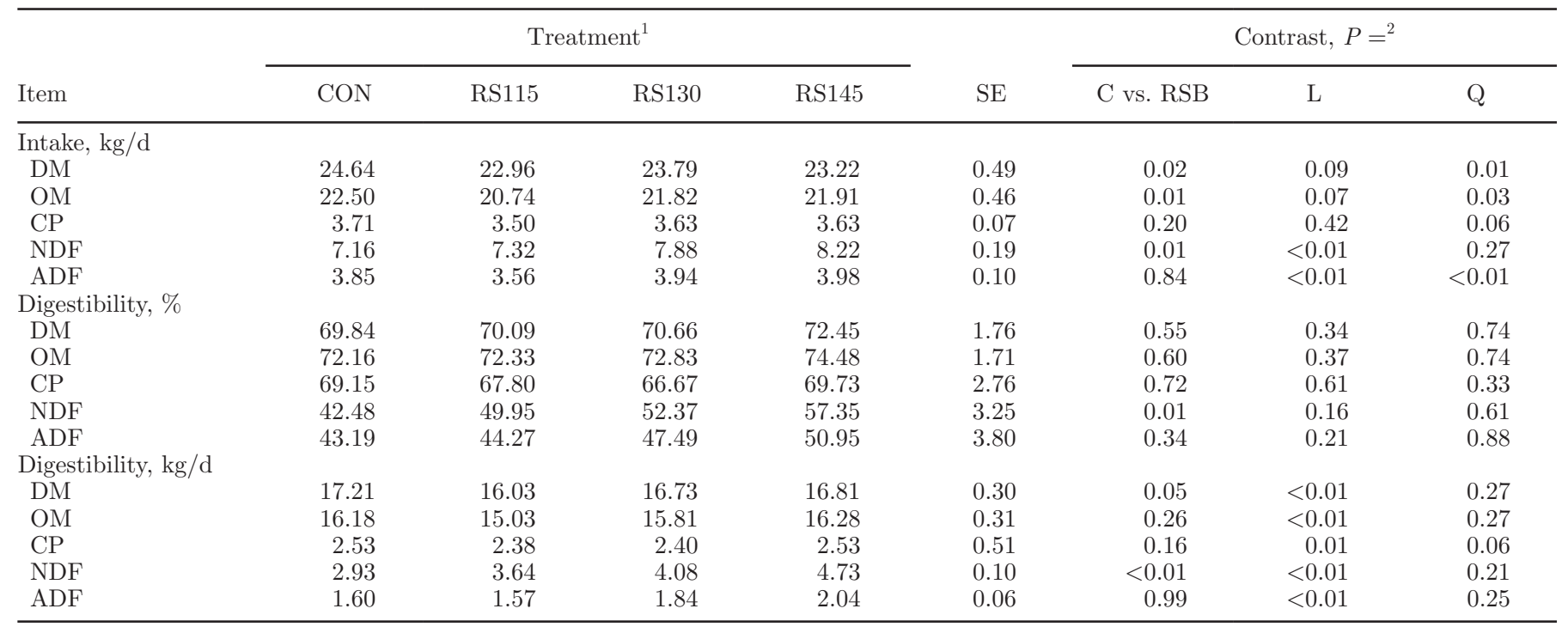

${ }^{1} \mathrm{CON}=$ calcium salts of fatty acids; $\mathrm{RS} 115=$ soybean roasted at $115^{\circ} \mathrm{C} ; \mathrm{RS} 130=$ soybean roasted at $130^{\circ} \mathrm{C} ; \mathrm{RS} 145=$ soybean roasted at $145^{\circ} \mathrm{C}$. ${ }^{2}$ Preplanned orthogonal contrasts were CON vs. all soybean-containing diets (C vs. RSB), and the linear (L) and quadratic (Q) effects of roasting temperature for all roasted diets. 
Table 4. Least squares means for plasma metabolites for cows fed calcium salts of fatty acids or ground whole soybeans roasted at different temperatures

\begin{tabular}{|c|c|c|c|c|c|c|c|c|}
\hline \multirow[b]{2}{*}{ Item } & \multicolumn{4}{|c|}{ Treatment $^{1}$} & \multirow[b]{2}{*}{$\mathrm{SE}$} & \multicolumn{3}{|c|}{ Contrast, $P=^{2}$} \\
\hline & $\mathrm{CON}$ & RS115 & RS130 & RS145 & & $\mathrm{C}$ vs. RSB & $\mathrm{L}$ & $\mathrm{Q}$ \\
\hline Albumin, g/dL & 4.08 & 4.06 & 4.12 & 4.11 & 0.08 & 0.86 & 0.56 & 0.95 \\
\hline Globulin, g/dL & 3.33 & 3.39 & 3.41 & 3.47 & 0.12 & 0.52 & 0.74 & 0.62 \\
\hline Albumin:globulin, $\mathrm{g} / \mathrm{g}$ & 1.23 & 1.20 & 1.21 & 1.18 & 0.04 & 0.60 & 0.90 & 0.83 \\
\hline Triglyceride, mg/dL & 8.20 & 7.83 & 8.02 & 8.02 & 0.26 & 0.42 & 0.90 & 0.53 \\
\hline $\mathrm{BHB}, \mu \mathrm{mol} / \mathrm{L}$ & 0.62 & 0.54 & 0.62 & 0.52 & 0.05 & 0.39 & 0.78 & 0.21 \\
\hline Uric acid, mg/dL & 1.30 & 1.37 & 1.36 & 1.38 & 0.08 & 0.47 & 0.91 & 0.70 \\
\hline
\end{tabular}

${ }^{1} \mathrm{CON}=$ calcium salts of fatty acids; $\mathrm{RS} 115=$ soybean roasted at $115^{\circ} \mathrm{C} ; \mathrm{RS} 130=$ soybean roasted at $130^{\circ} \mathrm{C} ; \mathrm{RS} 145=$ soybean roasted at $145^{\circ} \mathrm{C}$. ${ }^{2}$ Preplanned orthogonal contrasts were CON vs. all soybean-containing diets (C vs. RSB), and the linear (L) and quadratic (Q) effects of roasting temperature for all roasted diets.

ing whole soybeans had higher NDF digestibility than the control diet containing SBM. The improvement in total-tract digestibility of NDF in the soybean diets could be due, in part, to soybean seed NDF being more digestible than the fiber constituents of the basal diet (Tice et al., 1993; Aldrich et al., 1995). Additionally, the greater intake of NDF with the roasted soybean diets might have improved ruminal conditions for fiber fermentation (Wright et al., 2005). In contrast to our results, Aldrich et al. (1995) reported that the temperature of roasting had no effect on NDF digestibility.

\section{Plasma and Rumen Variables}

Plasma variables (Table 4) did not differ among treatments. Cows fed CON tended $(P=0.06)$ to have higher urea $\mathrm{N}$ concentration compared with those fed roasted soybean diets (13.06 vs. $11.19 \mathrm{mg} / \mathrm{dL}$ ).

Results for ruminal $\mathrm{NH}_{3} \mathrm{~N}$ and VFA concentrations are presented in Table 5 . The low $\mathrm{NH}_{3} \mathrm{~N}$ concentration (mean $7.7 \mathrm{mg} / \mathrm{dL}$ ) likely reflects the relatively low RDP content of the diets but $\mathrm{NH}_{3} \mathrm{~N}$ did not differ among treatments. Total VFA concentration (mean $86.5 \mathrm{~m} M$ ) and molar proportions of propionate $(20.8 \mathrm{~mol} / 100$ $\mathrm{mol})$, butyrate $(9.9 \mathrm{~mol} / 100 \mathrm{~mol})$, and acetate $(52.0$ $\mathrm{mol} / 100 \mathrm{~mol}$ ) in ruminal fluid were not affected by treatments. Molar proportions of isovalerate $(P=0.07)$ and the acetate to propionate ratio $(P=0.08)$ showed a quadratic response to the roasting temperatures. The proportion of isovalerate and acetate to propionate ratio were greater when cows were fed RS130 than either RS115 or RS145 (1.4 vs. 1.2 and $1.2 \mathrm{~mol} / 100 \mathrm{~mol}$, and 2.9 vs. 2.5 and 2.7 , respectively).

\section{Milk Yield and Composition}

Actual and component-corrected milk production (Table 6) was greater in cows fed CON than in cows fed diets containing roasted soybeans $(P<0.01)$. Also, a quadratic effect was found of roasting temperatures

Table 5. Least squares means for rumen parameters for cows fed calcium salts of fatty acids or ground whole soybeans roasted at different temperatures

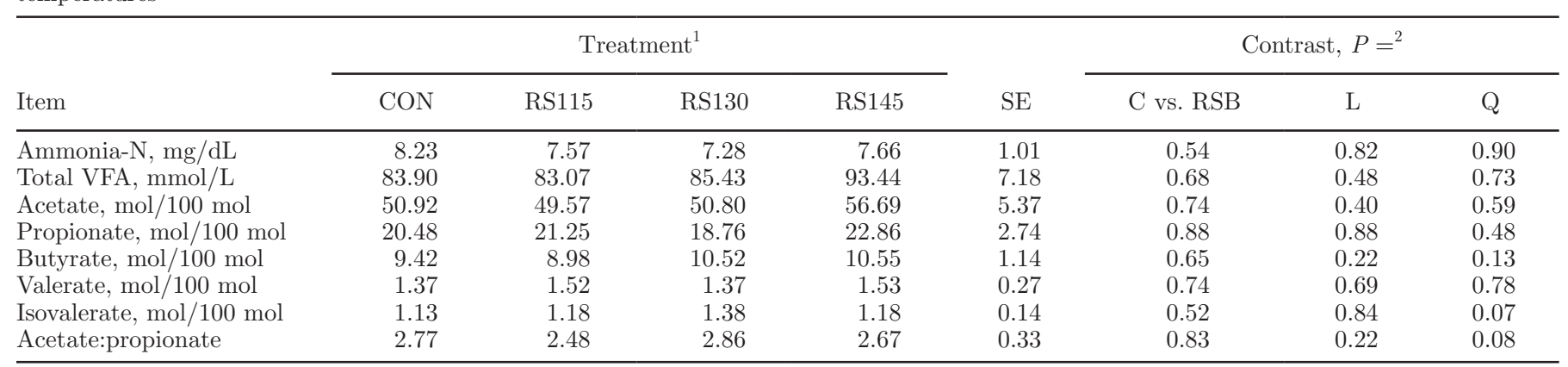

${ }^{1} \mathrm{CON}=$ calcium salts of fatty acids; $\mathrm{RS} 115=$ soybean roasted at $115^{\circ} \mathrm{C} ; \mathrm{RS} 130=$ soybean roasted at $130^{\circ} \mathrm{C} ; \mathrm{RS} 145=$ soybean roasted at $145^{\circ} \mathrm{C}$. ${ }^{2}$ Preplanned orthogonal contrasts were CON vs. all soybean-containing diets (C vs. RSB), and the linear (L) and quadratic (Q) effects of roasting temperature for all roasted diets. 
on actual milk yield $(P=0.01)$. Milk yield was lower for cows fed RS130 than for those fed either RS115 or RS145 (41.3 vs. 43.3 and $42.2 \mathrm{~kg} / \mathrm{d}$, respectively). Cows fed RS115 had higher milk production among diets containing roasted soybeans. Cows fed the CON diet had higher DMI, which likely resulted in greater milk and milk component yields. Greater milk production when cows were fed CON in this experiment also could be due to the higher amount of digestible RUP as compared with the roasted soybean treatments (Tice et al., 1993). Rabiee et al. (2012) reported in a meta-analysis study that cows fed Ca-FA had higher DMI and milk production than those cows fed soybean oil. Similar to our findings, Ipharraguerre et al. (2005) reported that cows fed lignosulfonate-treated SBM produced more milk than those fed roasted soybeans and there was no difference in milk composition among diets. No differences in milk production were detected between cows fed Ca-FA and those fed roasted (Dhiman et al., 1995) or extruded (Kim et al., 1993) soybeans, but Tice et al. (1993) reported greater milk yield for cows fed roasted soybeans than for cows fed Ca-FA.

No difference $(P>0.10)$ was found in concentrations of fat, protein, or TS between cows fed CON and those fed diets containing roasted soybeans (Table 6). Milk fat content averaged $3.27 \%$, which was typical for this herd and region. Milk fat, protein, and TS percentages demonstrated quadratic effects of roasting temperature $(P<0.01)$, with cows fed RS130 having greater milk fat, protein, and TS percentages compared with cows fed RS115 or RS145 $(P<0.01)$. In contrast to the results of the current experiment, roasting had no effect on milk fat and protein concentration in other studies (Bernard, 1990; Tice et al., 1993; Grummer et al., 1994). Roasted soybeans had no effect on milk protein content (Tice et al., 1993; Dhiman et al., 1995), but extruded soybeans increased the protein content as compared with Ca-FA (Kim et al., 1993). Milk fat was found to be decreased in cows fed roasted (Dhiman et al., 1995) or extruded (Kim et al., 1993) soybeans as compared with Ca-FA, and the reduction was greater for cows fed extruded soybeans than those fed roasted soybeans.

Milk protein content in the current study (average $2.81 \%$ across all treatments) may have been constrained by dietary RDP content and the added dietary lipid (DePeters and Cant, 1992). The concentration of MUN did not differ among diets $(P>0.10)$. The low MUN (mean $8.4 \mathrm{mg} / \mathrm{dL}$ ) agrees with the low ruminal $\mathrm{NH}_{3} \mathrm{~N}$ and likely reflects the low dietary RDP and high RUP (Kohn et al., 2002).

Efficiency (milk/DMI) was similar among CON and roasted soybean diets. Roasted diets showed a quadratic effect of roasting temperature $(P<0.01)$; cows fed RS130 had lower feed efficiency than those fed RS115 or RS145 (mean 1.75 vs. 1.91 and 1.84, respectively). Efficiency of $3.5 \%$ FCM yield (3.5\% FCM/ $\mathrm{DMI})$ tended to be higher for CON than for roasted soybean diets (1.82 vs. 1.73, respectively), because of higher milk production and milk fat content in CON.

Table 6. Least squares means for milk yield and composition for cows fed calcium salts of fatty acids or ground whole soybeans roasted at different temperatures

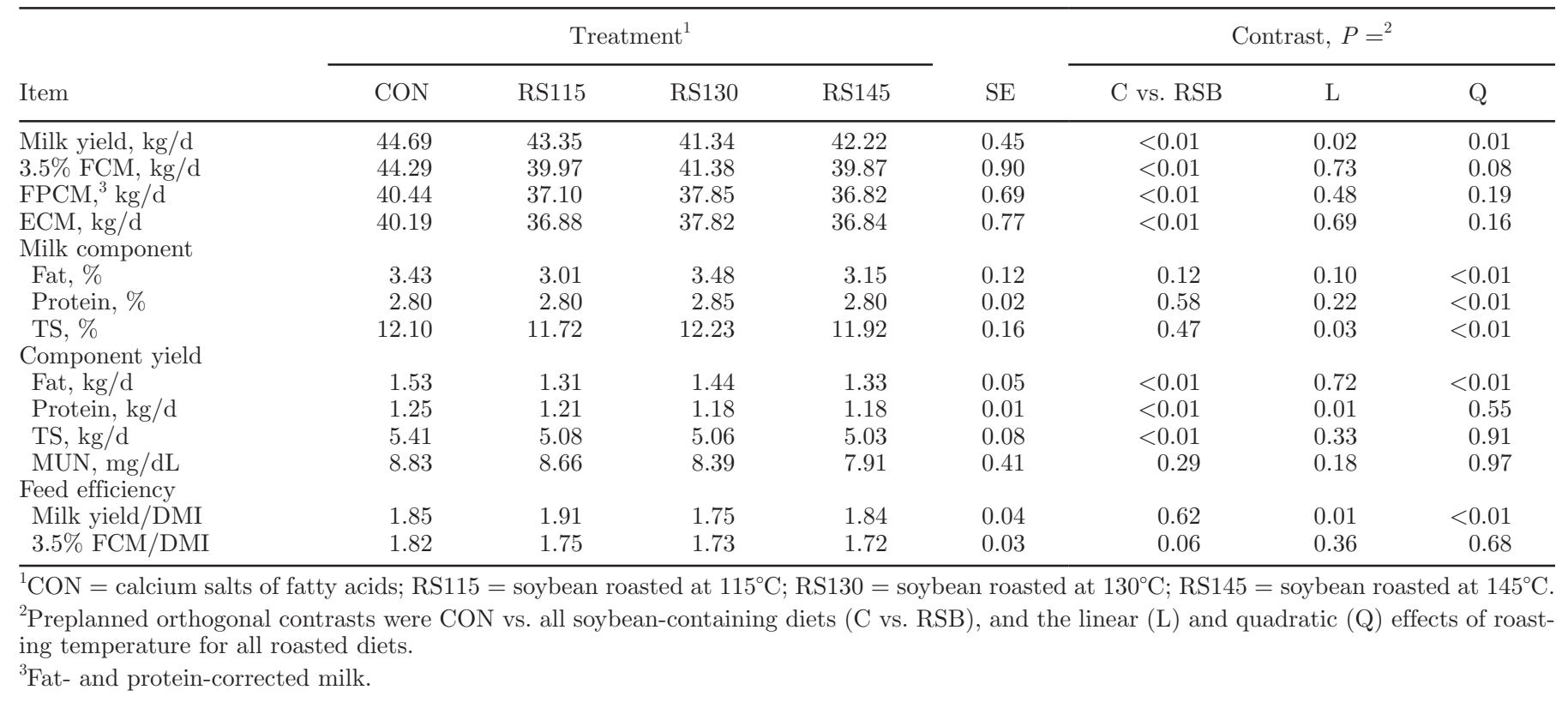


Table 7. Least squares means for milk fatty acid profile (g/100 g total fatty acids) for cows fed calcium salts of fatty acids or ground whole soybeans roasted at different temperatures

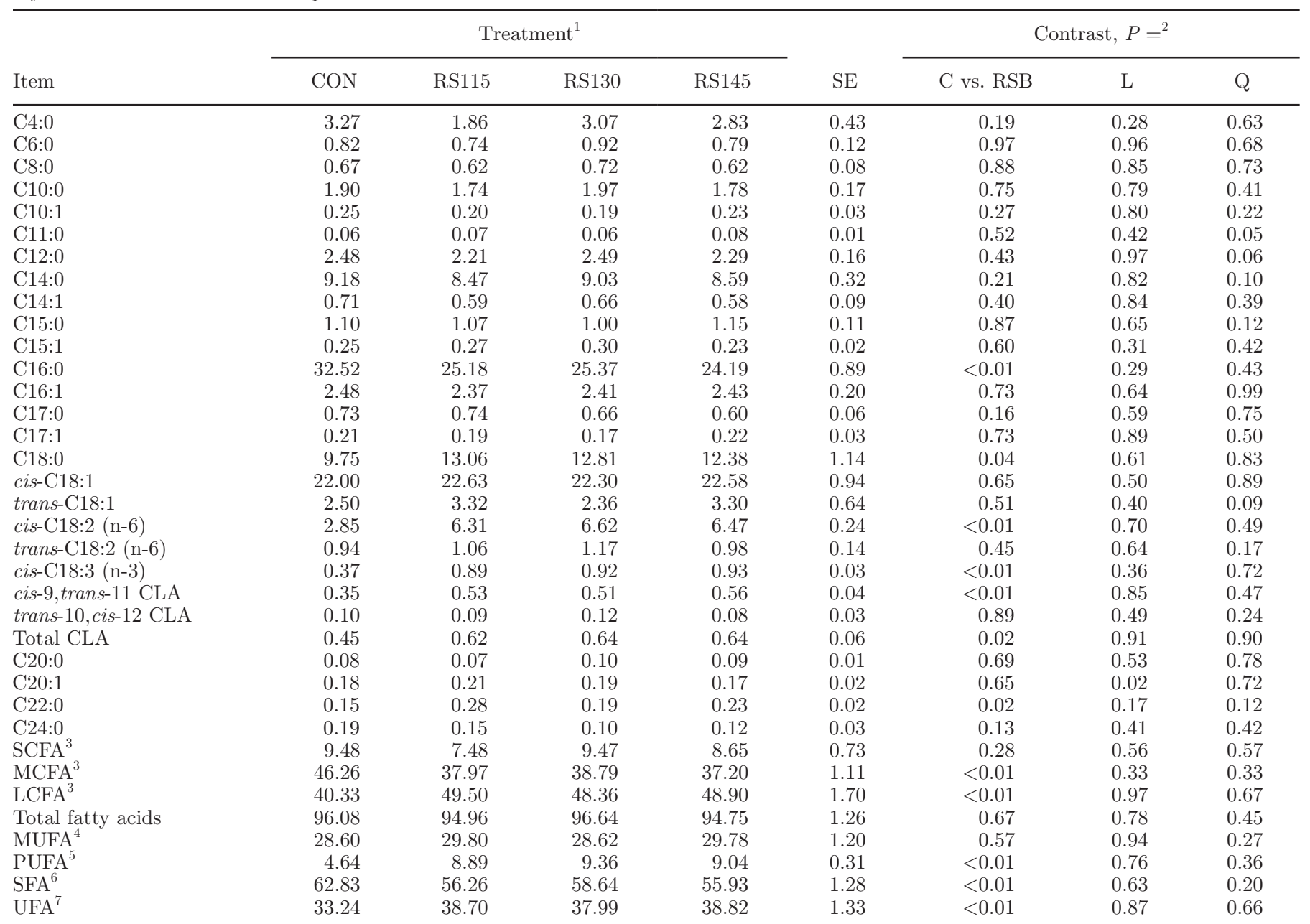

${ }^{1} \mathrm{CON}=$ calcium salts of fatty acids; $\mathrm{RS} 115=$ soybean roasted at $115^{\circ} \mathrm{C} ; \mathrm{RS} 130=$ soybean roasted at $130^{\circ} \mathrm{C} ; \mathrm{RS} 145=$ soybean roasted at $145^{\circ} \mathrm{C}$. ${ }^{2}$ Preplanned orthogonal contrasts were CON vs. all soybean-containing diets (C vs. RSB), and the linear (L) and quadratic (Q) effects of roasting temperature for all roasted diets.

${ }^{3} \mathrm{SCFA}=$ short-chain fatty acids (4:0 to 12:0), MCFA = medium-chain fatty acids (14:0 to 17:0), LCFA = long-chain fatty acids (18:0 to 24:0).

${ }^{4}$ Sum of MUFA $=\mathrm{C} 10: 1+\mathrm{C} 14: 1+\mathrm{C} 15: 1+\mathrm{C} 16: 1+\mathrm{C} 17: 1+$ cis-C18:1 + trans-C18:1 + C20:1.

${ }^{5} \mathrm{Sum}$ of PUFA $=$ cis-C18:2 + trans-C18:2 + cis-C18:3 + cis-9,trans-11-CLA + trans-10, cis-12-CLA.

${ }^{6} \mathrm{Sum}$ of SFA $=\mathrm{C} 4: 0+\mathrm{C} 6: 0+\mathrm{C} 8: 0+\mathrm{C} 11: 0+\mathrm{C} 12: 0+\mathrm{C} 14: 0+\mathrm{C} 15: 0+\mathrm{C} 16: 0+\mathrm{C} 17: 0+\mathrm{C} 18: 0+\mathrm{C} 20: 0+\mathrm{C} 22: 0+\mathrm{C} 24: 0$.

${ }^{7} \mathrm{Sum}$ of UFA $=\mathrm{C} 10: 1+\mathrm{C} 14: 1+\mathrm{C} 15: 1+\mathrm{C} 16: 1+\mathrm{C} 17: 1+$ cis-C18:1 + trans-C18:1 + cis-C18:2 + trans-C18:2 + cis-C18:3 + cis-9,trans-11CLA + trans-10, cis-12-CLA + C20:1.

\section{Milk Fatty Acid Composition}

Effects of unsaturated oils from oilseeds on milk fatty acid profile have been widely documented in the literature (Lourenco et al., 2010; Resende et al., 2015). Because total dietary fatty acids were equalized in our study, contents of the individual short-chain fatty acid (SCFA) from C4:0 to C12:0 and the medium-chain fatty acid (MCFA) C14:0 through C15:1 were not different between cows fed CON and those fed roasted soybeans (Table 7 ). Contents of $\mathrm{C} 11: 0$ and $\mathrm{C} 12: 0$ were affected quadratically as temperature of roasted soybeans increased; content of C12:0 was highest, and content of C11:0 the lowest, for cows fed RS130. Although contrasts were not significant for C4:0, C6:0, C8:0, and C10:0, means followed the same pattern among treatments as for C12:0, suggesting a common effect of roasting temperature for these fatty acids synthesized de novo.

Feeding roasted soybeans decreased the proportion of C16:0 fatty acids by $24 \%$ in comparison with the CON diet (Table $7, P<0.01$ ), which might be explained by 
differences in C16 and C18 fatty acids supplied by CaFA and soybeans. In agreement with this result, diets with roasted (Mohamed et al., 1988; Dhiman et al., 1995) or extruded (Chouinard et al., 1997a,b; Solomon et al., 2000; Neves et al., 2007) soybeans resulted in less C16:0 fatty acids compared with the SBM or raw soybeans used as controls. Content of C16:1 was not affected by treatment.

Mammary enzymatic systems cannot extend the carbon chain from $\mathrm{C} 16$ to $\mathrm{C} 18$; therefore, diet is responsible for the $\mathrm{C} 18$ fatty acid content in milk either directly or after storage and release in adipose tissues (Grummer, 1991; Dhiman et al., 1995). Cows fed diets with roasted soybeans had greater $(P<0.01)$ contents of $\mathrm{C} 18: 0$ (12.75 vs. 9.57 , by $33 \%$ ), cis-C18:2 (6.46 vs. 2.85 , by $126 \%$ ), and cis-C18:3 (0.91 vs. 0.37 , by $145 \%$ ) than those fed CON. In line with the results of the current experiment, feeding cows roasted (Tice et al., 1994; Dhiman et al., 1995, 2000) or extruded (Kim et al., 1993) soybeans increased C18:0, C18:2, and C18:3 fatty acids in milk. Oil is released slowly from oilseeds in the rumen, with a relatively lower probability of biohydrogenation in comparison to the same quantity of free oil (Dhiman et al., 1995). Feeding oil through whole seeds also makes more UFA available for absorption in the small intestine (Dhiman et al., 1995). Therefore, the increases of C18:2 and C18:3 in the milk fat of cows fed roasted soybean diets reflect their rumen escape and high transfer efficiency to milk fat.

Despite the greater C18:0 in milk when cows were fed diets with roasted soybeans, milk fat content of cis-C18:1 was not affected by diets (Table 7 ). Activity of $\Delta^{9}$-desaturase in mammary gland normally converts a portion of C18:0 to cis-C18:1 (Dhiman et al., 2000). Our results indicate that $\Delta^{9}$-desaturase may have been inhibited by one or more of the C18 fatty acids absorbed by cows fed diets containing roasted soybeans.

The contents of cis-9,trans-11-C18:2 (increased 51\%; $P<0.01$ ), total CLA (increased $40 \% ; P=0.02$ ), and C22:0 (increased 53\%; $P=0.02$ ) were greater in milk from cows fed diets containing roasted soybeans compared with CON (Table 7). Previous studies, such as Dhiman et al. (1999, 2000), Solomon et al. (2000), AbuGhazaleh et al. (2002), and Neves et al. (2007), have observed a similar result. Treatment contrasts were not significant for any of the other trans fatty acids present in milk fat.

Treatments had no effect on total SCFA, but total MCFA were greater $(P<0.01)$ for CON $(46.3$ vs. 38.0$)$ than for diets with roasted soybeans (Table 7). Inversely, long-chain fatty acids (LCFA), which represent those taken up by the mammary gland from the blood, were increased by the roasted soybean diets $(P<0.01,48.9$ vs. 40.3). In previous studies, use of extruded (Kim et al., 1993; Neves et al., 2007) or roasted (McNiven et al., 1994; Tice et al., 1994) soybeans in the diet of dairy cows showed similar results. The MCFA are extensively synthesized de novo in the epithelial cells of the mammary gland; therefore, their synthesis can be inhibited when dietary provision of certain LCFA is increased (Grummer, 1991). In terms of human health, reduction of MCFA may represent an improvement in the fatty acid profile of milk because MCFA has been reported to constitute the hypercholesterolemic portion of milk fat (Shingfield et al., 2013).

Contents of UFA and PUFA were increased in milk of cows fed the roasted soybean diets $(P<0.01)$, whereas SFA were higher for CON than the roasted soybean diets $(P<0.01)$. Treatments had no effect on contents of MUFA. The increase in PUFA in the mammary gland could explain the reduction of MCFA in milk from cows fed roasted soybeans. The PUFA compete for esterification with MCFA synthesized in the mammary gland, causing a feedback inhibition of lipogenic enzymes (Caroprese et al., 2011). Liu et al. (2008) noted a reduction in the milk concentrations of SCFA and MCFA when cows were fed diets containing roasted oilseeds. They also reported an increase in cis-9,trans-11-CLA content in the milk fat of cows fed roasted oilseeds. In our study, the increase in milk PUFA indicates that a portion of the oil escaped ruminal metabolism and saturation.

Certain dietary situations, including low-fiber diets and greater plant oil intake, can cause a reduction in milk fat secretion. The biohydrogenation theory established that diet-induced milk fat depression in dairy cows is caused by an inhibition of mammary lipogenesis by specific fatty acid isomers produced during ruminal biohydrogenation of UFA (Bauman et al., 2011). Changes in the ruminal environment can lead to a change in the isomers of CLA produced by the rumen microbial population. Low rumen $\mathrm{pH}$ caused an increase in the concentration of trans-10, cis-12-CLA but no change in cis-9,trans-11-CLA (Jenkins and Harvatine, 2014). The reduction in milk fat output is highly correlated with increases in milk fat content of trans-18:1 and CLA isomers. The trans-10,cis-12-CLA isomer appears to be a major causative fatty acid, and trans-10-18:1 is a marker of milk fat reduction in dairy cows (Griinari et al., 1998; Bauman et al., 2011). In our study, however, the content of trans-10,cis-12-CLA was only weakly $(P<0.10)$ correlated with milk fat percentage $(\mathrm{r}=$ $-0.32)$ or yield $(\mathrm{r}=-0.35)$. Negative correlations were stronger $(P<0.01)$ between total trans-C18:1 content and either milk fat percentage $(\mathrm{r}=-0.60)$ or yield $(\mathrm{r}$ $=-0.54$ ), although the responsible isomer or isomers could not be determined. 


\section{Health Indices in Milk}

Modification of milk fatty acid composition to fit more closely with human medical and nutritional goals remains a topic of interest (Jenkins et al., 2008; Lourenc et al., 2010; Shingfield et al., 2013). One proposal for the ideal fatty acid composition of milk fat of dairy cows (from a human health perspective) was that milk fat would contain 10\% PUFA, $8 \%$ SFA, and $82 \%$ MUFA; however, typical milk fat contains about $70 \%$ SFA, 25\% MUFA, and 5\% PUFA (Jenkins and McGuire, 2006). The high proportions of SFA in milk fat, such as C12:0, C14:0, and C16:0, are related to an increased risk of atherosclerosis, hyperlipidemia, and low-density lipoprotein cholesterol (Bobe et al., 2007). The UFA have been considered healthy fats because of their anticarcinogenic, antiatherogenic, antidiabetic, and antiadipogenic properties (Lourenc et al., 2010; Dilzer and Yeonhwa, 2012). Desirable alterations in milk fatty acids in response to human health are to increase the amounts of MUFA and PUFA and to decrease the amounts of SFA, particularly C12:0, C14:0, and C16:0. The fatty acid content of milk fat from dairy cows can be manipulated through the diet, such as feeding oilseeds (Dhiman et al., 1999). Ratios of PUFA/SFA, n-6/n-3 PUFA, hypocholesterolemic fatty acids/hypercholesterolemic fatty acids $(\mathbf{h H})$, atherogenic index (ATI), and thrombogenic index (TI) have been used to evaluate the nutritional value of milk fat. Bobe et al. (2007) developed another index, termed health-promoting index (HPI; the inverse of the atherogenic index). The effects of treatments on indices used to predict health effects of milk are presented in Table 8.

Because of higher percentage of PUFA in milk of cows fed roasted soybean diets (Table 7), the PUFA/ SFA and SFA/UFA ratios were higher and lower, respectively, when cows were fed roasted soybean diets in comparison with the CON diet (0.15 and 1.49 vs. 0.07 and 1.89). Feeding roasted soybeans decreased the ratio of n- $6 / \mathrm{n}-3$ PUFA by $26 \%$ in comparison with CON ( $P$ $<0.01$ ) because of higher C18:3 in roasted soybean diets. Consumption of n-3 PUFA had positive effects on human health (Caroprese et al., 2011). The reduction in MCFA (particularly C16:0, by 30\%) and increase in PUFA (by 95\%) in milk of cows fed roasted soybean diets in comparison with CON caused consequent reductions in ATI and TI and increases in $\mathrm{hH}$ ratio and HPI in milk of cows fed roasted soybean diets. Milk fat with high ATI and TI values may be more likely to contribute to development of atherosclerosis or coronary thrombosis in humans, whereas milk with high HPI index and hH ratio (including more CLA and PUFA) may have a protective effect against cardiovascular diseases. McNiven et al. (2004) found that meat from

Table 8. Least squares means for health lipid indices in milk of cows fed calcium salts of fatty acids or ground whole soybeans roasted at different temperatures

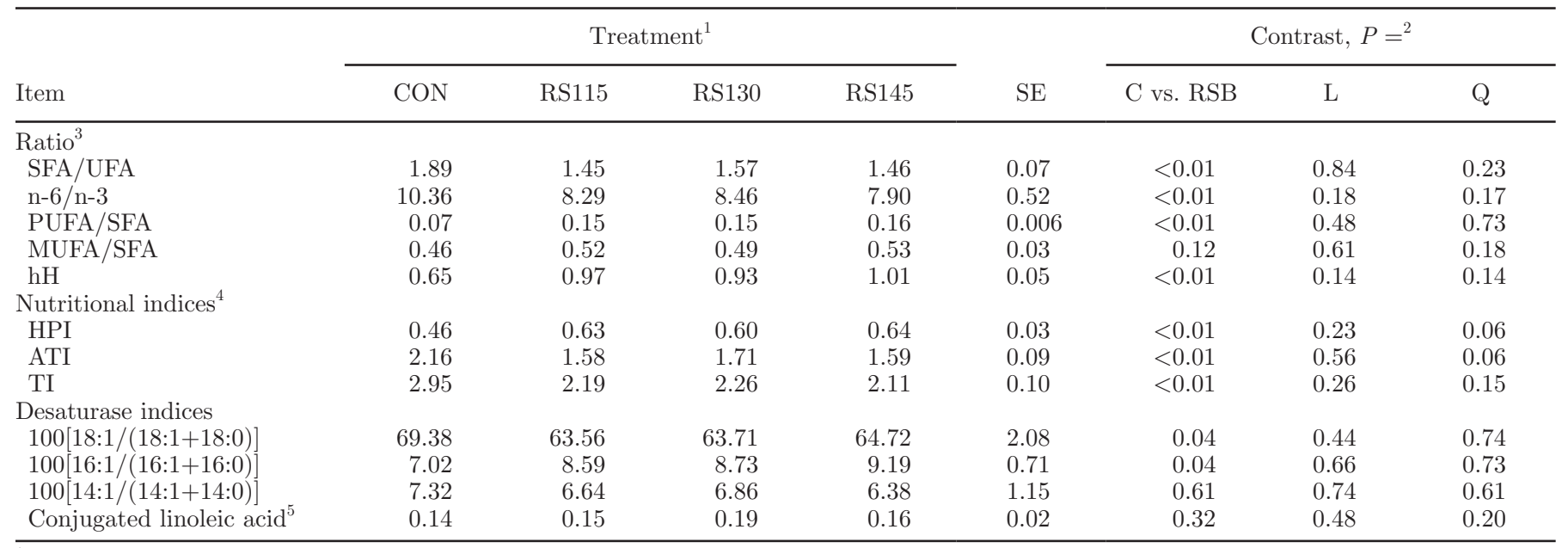

${ }^{1} \mathrm{CON}=$ calcium salts of fatty acids; RS115 = soybean roasted at $115^{\circ} \mathrm{C} ; \mathrm{RS} 130=$ soybean roasted at $130^{\circ} \mathrm{C} ; \mathrm{RS} 145=$ soybean roasted at $145^{\circ} \mathrm{C}$. ${ }^{2}$ Preplanned orthogonal contrasts were CON vs. all soybean-containing diets (C vs. RSB), and the linear (L) and quadratic (Q) effects of roasting temperature for all roasted diets.

${ }^{3} \mathrm{SFA} / \mathrm{UFA}=$ sum of SFA/sum of UFA; n-6/n-3 = sum of n- 6 fatty acids/sum of n-3 fatty acids; PUFA/SFA = sum of PUFA/sum of SFA; MUFA/SFA $=$ sum of MUFA/sum of SFA; hH: hypocholesterolemic/hypercholesterolemic index $=(\mathrm{C} 18: 1+\mathrm{PUFA}) /(\mathrm{C} 12: 0+\mathrm{C} 14: 0+\mathrm{C} 16: 0)$.

${ }^{4} \mathrm{HPI}$ : health-promoting index $=($ sum of $\%$ of UFA $) /(\% 12: 0+4 \times \% 14: 0+\% 16: 0) ;$ ATI: atherogenic index $=(\% 12: 0+4 \times \% 14: 0+\% 16: 0) /$ $($ sum of $\%$ of UFA); TI: thrombogenic index $=(\% 14: 0+\% 16: 0+\% 18: 0) /[(0.5 \times$ MUFA $\%)+(0.5 \times \mathrm{n}-6$ PUFA $\%)+(3 \times \mathrm{n}-3$ PUFA $\%)+(\mathrm{n}-3$ PUFA/n-6 PUFA).

${ }^{5} 100 \times[$ cis-9,trans-11 CLA $] /[$ cis-9,trans-11 CLA + trans-11 18:1]. 
steers fed roasted soybeans had lower concentrations of the hypercholesterolemic MCFA and higher amounts of the hypocholesterolemic UFA compared with steers fed raw or extruded soybeans. Bobe et al. (2007) reported that HPI was increased in butter when cows were fed diets containing extruded soybeans, primarily from increased proportions of $c i s-\mathrm{C} 18: 2$ and cis-C$^{-} 18: 3$ in the milk fat.

Ratios of product/(substrate + product), called the desaturase indices (DI), were estimated to assess the extent of desaturation of specific fatty acids during milk fat synthesis (Kelsey et al., 2003). The enzyme $\Delta^{9}$ desaturase catalyzes the introduction of a cis-double bond between carbons 9 and 10 of SFA with a chain length of 10 to 18 carbons, thus converting specific medium and long-chain SFA into the corresponding MUFA (Kelsey et al., 2003). Treatments had no effect on DI-14 and DI-CLA; however, milk from cows fed CON diet had lower DI-16 and higher DI-18 than milk from cows fed roasted soybean diets $(P<0.05)$. Roasting temperature had no effect on the DI or health indices in milk $(P>0.10)$, except for the tendency $(P$ $=0.06)$ for a quadratic effect on ATI and HPI.

It is currently estimated that the average adult consumes only one-third to one-half of the amount of CLA that has been shown to reduce cancer in animal studies. For this reason, increasing the CLA contents of milk and meat remains an option to raise the nutritive and therapeutic values of dairy products and meat (Dhiman et al., 2005). The cis-9,trans-11-CLA isomer, which arises primarily from the biohydrogenation of linoleic acid (Jenkins and McGuire, 2006), has received the most attention because of its anticarcinogenic properties. Recently, clinical studies have implicated excessive consumption of medium-chain SFA and transfatty acids as risk factors for cardiovascular disease. Ruminant-originated foods are significant sources of medium-chain SFA and trans fatty acids in the human diet. Oilseed supplements can be used to lower mediumchain and total SFA content and increase cis-9-18:1, total CLA, n-3 PUFA, and n-6 PUFA in ruminant milk (Shingfield et al., 2013). In the current trial, feeding roasted soybeans increased cis-C18:2, cis-C18:3, and cis-9,trans-11-CLA proportions in milk fat compared with the Ca-FA control $(P<0.05)$, whereas trans-fatty acids was similar between treatments. Overall, cows fed roasted soybeans produced milk with higher CLA and PUFA content, similar trans-fatty acids, and lower ATI and TI than cows fed Ca-FA, suggesting that utilization of roasted soybeans might result in milk more favorable to reduction of atherosclerosis and coronary thrombosis risk associated with the consumption of milk and dairy products.

\section{CONCLUSIONS}

In this study, the CON diet containing Ca-FA resulted in higher DMI and milk production than diets containing roasted soybeans, but milk efficiency was not different among diets. Treatments had no effect on rumen and blood variables. Cows fed RS130 had higher DMI and milk fat percentage than cows fed RS115 or RS145; however, milk yield was lower for cows fed RS130. In general, it seems possible to adjust milk fatty acid composition toward more favorable profiles for human nutrition by feeding roasted soybeans to dairy cows. Roasted soybeans enhanced LCFA, PUFA, and CLA contents of milk fat, without a consistent effect on milk fat content. The utilization of roasted soybeans in diets enhanced cis fatty acids in milk; however, those diets had no effect on trans fatty acids. Changes in milk fatty acids were consistent with a healthier image of milk for humans. Roasting temperature had little effect on milk fatty acid profile. The changes of milk fatty acids did not seem to explain the lower milk fat for cows fed RS115 or RS145.

\section{ACKNOWLEDGMENTS}

The authors thank the staff of the Dairy Research and Teaching Unit of Isfahan University of Technology for the technical assistance. We also thank Mehr Bisotun Co. (Isfahan, Iran) and Sanadam Pars Co. (Tehran, Iran) for their financial and technical support.

\section{REFERENCES}

Abdi, E., F. Fatahnia, M. Dehghan Banadaki, A. Azarfar, and A. Khatibjoo. 2013. Effects of soybeans roasting and monensin on milk production and composition and milk fatty acids profile of lactating dairy cows. Livest. Sci. 153:73-80.

Abel-Caines, S. F., R. J. Grant, T. J. Klopfenstein, T. Winowiski, and N. Barney. 1998. Influence of nonenzymatically browned soybeans on ruminal fermentation and lactational performance of dairy cows. J. Dairy Sci. 81:1036-1045.

Abu-Ghazaleh, A. A., D. J. Schingoethe, A. R. Hippen, and L. A. Whitlock. 2002. Feeding fish meal and extruded soybeans enhances the conjugated linoleic acid (CLA) content of milk. J. Dairy Sci. 85:624-631.

Akbarian, A., M. Khorvash, G. R. Ghorbani, E. Ghasemi, M. Dehghan-Banadaky, P. Shawrang, and M. H. Ghaffari. 2014. Effects of roasting and electron beam irradiating on protein characteristics, ruminal degradability and intestinal digestibility of soybean and the performance of dairy cows. Livest. Sci. 168:45-52.

Aldrich, C. G., N. R. Merchen, and J. K. Drackley. 1995. The effect of roasting temperature applied to whole soybeans on site of digestion by steers: I. Organic matter, energy, fiber, and fatty acid digestion. J. Anim. Sci. 73:2120-2130.

Allen, M. S. 2000. Effects of diet on short-term regulation of feed intake by lactating dairy cattle. J. Dairy Sci. 83:1598-1624.

AOAC International. 2002. Official Methods of Analysis. 17th ed. AOAC International, Arlington, VA. 
ASAE. 1995. Method of determining and expressing fineness of feed material by sieving. Page 461 in ASAE Standards 1995. American Society of Agricultural Engineers, St. Joseph, MI.

Bahrami-Yekdangi, H., M. Khorvash, G. R. Ghorbani, M. Alikhani, R. Jahanian, and E. Kamalian. 2014. Effects of decreasing metabolizable protein and rumen-undegradable protein on milk production and composition and blood metabolites of Holstein dairy cows in early lactation. J. Dairy Sci. 97:3707-3714.

Bal, M. A., R. D. Shaver, A. G. Jirovec, K. J. Shinners, and J. G. Coors. 2000. Crop processing and chop length of corn silage: Effects on intake, digestion, and milk production by dairy cows. J. Dairy Sci. 83:1264-1273.

Bauman, D. E., K. J. Harvatine, and A. L. Lock. 2011. Nutrigenomics, rumen-derived bioactive fatty acids, and the regulation of milk fat synthesis. Annu. Rev. Nutr. 31:299-319.

Bernard, J. K. 1990. Effect of raw or roasted whole soybeans on digestibility of dietary nutrients and milk production of lactating dairy cows. J. Dairy Sci. 73:3231-3236.

Bobe, G., S. Zimmerman, E. G. Hammond, A. E. Freeman, P. A. Porter, C. M. Luhman, and D. C. Beitz. 2007. Butter composition and texture from cows with different milk fatty acid compositions fed fish oil or roasted soybeans. J. Dairy Sci. 90:2596-2603.

Broderick, G. A., and J. H. Kang. 1980. Automated simultaneous determination of ammonia and total amino acids in ruminal fluid and in vitro media. J. Dairy Sci. 63:64-75.

Calsamiglia, S., and M. D. Stern. 1995. A three-step in vitro procedure for estimating intestinal digestion of protein in ruminants. J. Anim. Sci. 73:1459-1465.

Caroprese, M., M. Albenzio, A. Bruno, V. Fedele, A. Santillo, and A. Sevi. 2011. Effect of solar radiation and flaxseed supplementation on milk production and fatty acid profile of lactating ewes under high ambient temperature. J. Dairy Sci. 94:3856-3867.

Chouinard, P. Y., V. Girard, and G. J. Brisson. 1997a. Performance and profiles of milk fatty acids of cows fed full fat, heat-treated soybeans using various processing methods. J. Dairy Sci. 80:334342 .

Chouinard, P. Y., V. Girard, and G. J. Brisson. 1997b. Dietary soybeans extruded at different temperatures: Milk composition and in situ fatty acid reactions. J. Dairy Sci. 80:2913-2924.

Cooke, K. M., J. K. Bernard, and J. W. West. 2008. Performance of dairy cows fed annual ryegrass silage and corn silage with steamflaked or ground corn. J. Dairy Sci. 91:2417-2422.

DePeters, E. J., and J. P. Cant. 1992. Nutritional factors influencing the nitrogen composition of bovine milk: A review. J. Dairy Sci. 75:2043-2070.

Dhiman, T. R., E. D. Helmink, D. J. Mcmahon, R. L. Fife, and M. W. Pariza. 1999. Conjugated linoleic acid content of milk and cheese from cows fed extruded oilseeds. J. Dairy Sci. 82:412-419.

Dhiman, T. R., S. H. Nam, and A. L. Ure. 2005. Factors affecting conjugated linoleic acid content in milk and meat. Crit. Rev. Food Sci. Nutr. 45:463-482.

Dhiman, T. R., L. D. Satter, M. W. Pariza, M. P. Galli, K. Albright, and M. X. Tolosa. 2000. Conjugated linoleic acid (CLA) content of milk from cows offered diets rich in linoleic and linolenic acid. J. Dairy Sci. 83:1016-1027.

Dhiman, T. R., K. V. Zanten, and L. D. Satter. 1995. Effect of dietary fat source on fatty acid composition of cows' milk. J. Sci. Food Agric. 69:101-107.

Dilzer, A., and P. Yeonhwa. 2012. Implication of conjugated linoleic acid (CLA) in human health. Crit. Rev. Food Sci. Nutr. 52:488513.

Faldet, M. A., and L. D. Satter. 1991. Feeding heat-treated full fat soybeans to cows in early lactation. J. Dairy Sci. 74:3047-3054.

Faldet, M. A., Y. S. Son, and L. D. Satter. 1992. Chemical, in vitro, and in vivo evaluation of soybeans heat-treated by various processing methods. J. Dairy Sci. 75:789-795.

Griinari, J. M., D. A. Dwyer, M. A. McGuire, D. E. Bauman, D. L. Palmquist, and K. V. V. Nurmela. 1998. Trans-octadecenoic acids and milk fat depression in lactating dairy cows. J. Dairy Sci. $81: 1251-1261$.
Grummer, R. R. 1991. Effect of feed on the composition of milk fat. J. Dairy Sci. 74:3244-3257.

Grummer, R. R., L. Melissa, and L. J. A. Barmore. 1994. Lactational performance of dairy cows fed raw soybeans, with or without animal by-product proteins, or roasted soybeans. J. Dairy Sci. 77:1354-1359.

Ipharraguerre, I. R., J. H. Clark, and D. E. Freeman. 2005. Rumen fermentation and intestinal supply of nutrients in dairy cows fed rumen-protected soy products. J. Dairy Sci. 88:2879-2892.

Iranian Council of Animal Care. 1995. Guide to the care and use of experimental animals. Vol. 1. Isfahan University of Technology, Isfahan, Iran.

Jenkins, T. C., and K. J. Harvatine. 2014. Lipid feeding and milk fat depression. Vet. Clin. North Am. Food Anim. Pract. 30:623-642.

Jenkins, T. C., and M. A. McGuire. 2006. Major advances in nutrition: Impact on milk composition. J. Dairy Sci. 89:1302-1310.

Jenkins, T. C., R. J. Wallace, P. J. Moate, and E. E. Mosley. 2008. Recent advances in biohydrogenation of unsaturated fatty acids within the rumen microbial ecosystem. J. Anim. Sci. 86:397-412.

Kelsey, J. A., B. A. Corl, R. J. Collier, and D. E. Bauman. 2003 The effect of breed, parity, and stage of lactation on conjugated linoleic acid (CLA) in milk fat from dairy cows. J. Dairy Sci. $86: 2588-2597$

Khorasani, G. R., G. de Boer, P. H. Robinson, and J. J. Kennelly. 1992. Effect of canola fat on ruminal and total tract digestion, plasma hormones, and metabolites in lactating dairy cows. J. Dairy Sci. 75:492-501.

Kim, Y. K., D. J. Schingoethe, D. P. Casper, and F. C. Ludens. 1993. Supplemental dietary fat from extruded soybeans and calcium salts of fatty acids for lactating dairy cows. J. Dairy Sci. 76:197-204.

Knapp, D. M., R. R. Grummer, and M. R. Dentine. 1991. The response of lactating dairy cows to increasing levels of whole roasted soybeans. J. Dairy Sci. 74:2563-2572.

Kohn, R. A., K. F. Kalscheur, and E. Russek-Cohen. 2002. Evaluation of models to estimate urinary nitrogen and expected milk urea nitrogen. J. Dairy Sci. 85:227-233.

Licitra, G., T. M. Hernandez, and P. J. Van Soest. 1996. Standardization of procedures for nitrogen fractionation of ruminant feeds. Anim. Feed Sci. Technol. 57:347-358.

Liu, Z. L., D. P. Yang, P. Chen, S. B. Lin, X. Y. Jiang, W. S. Zhao, J. M. Li, and W. X. Dong. 2008. Effect of dietary sources of roasted oilseeds on blood parameters and milk fatty acid composition. Czech J. Anim. Sci. 53:219-226.

Loor, J. J., A. Ferlay, A. Ollier, M. Doreau, and Y. Chilliard. 2005. Relationship among trans and conjugated fatty acids and bovine milk fat yield due to dietary concentrate and linseed oil. J. Dairy Sci. 88:726-740.

Lourenco, M., E. Ramos-Morales, and R. J. Wallace. 2010. The role of microbes in rumen lipolysis and biohydrogenation and their manipulation. Animal 4:1008-1023.

McNiven, M. A., J. Duynisveld, E. Charmley, and A. Mitchell. 2004. Processing of soybean affects meat fatty acid composition and lipid peroxidation in beef cattle. Anim. Feed Sci. Technol. 116:175-184.

McNiven, M. A., P. H. Robinson, and J. A. MacLeod. 1994. Evaluation of a new high protein variety of soybeans as a source of protein and energy for dairy cows. J. Dairy Sci. 77:2605-2613.

Mohamed, O. E., L. D. Satter, R. R. Grummer, and F. R. Ehle. 1988. Influence of dietary cottonseed and soybean on milk production and composition. J. Dairy Sci. 71:2677-2688.

Moshtaghi Nia, S. A., and J. R. Ingalls. 1992. Effect of heating on canola meal protein degradation in the rumen and digestion in the lower gastrointestinal tract of steers. Can. J. Anim. Sci. 72:83-88.

Mustafa, A. F., D. A. Christensen, J. J. McKinnon, and R. Newkirk. 2000. Effects of stage of processing of canola seed on chemical composition and in vitro protein degradability of canola meal and intermediate products. Can. J. Anim. Sci. 80:211-214.

Mustafa, A. F., J. J. McKinnon, and D. A. Christensen. 1999. Effect of moist heat treatment on in vitro degradability and ruminal escape protein and amino acids of mustard meal. Anim. Feed Sci. Technol. $76: 265-274$ 
National Research Council. 2001. Nutrient Requirements of Dairy Cattle. 7th rev. ed. Natl. Acad. Press, Washington, DC.

Neves, C. A., G. T. D. Santos, and M. Matsushita. 2007. Intake, digestibility, milk production, and milk composition of Holstein cows fed extruded soybeans treated with lignosulfonate. Anim. Feed Sci. Technol. 134:32-44.

Rabiee, A. R., K. Breinhild, W. Scott, H. M. Golder, E. Block, and I. J. Lean. 2012. Effect of fat additions to diets of dairy cattle on milk production and components: A meta-analysis and metaregression. J. Dairy Sci. 95:3225-3247.

Resende, T. L., J. Kraft, K. J. Soder, A. B. D. Pereira, D. E. Woitschach, R. B. Reis, and A. F. Brito. 2015. Incremental amounts of ground flaxseed decrease milk yield but increase n-3 fatty acids and conjugated linoleic acids in dairy cows fed high-forage diets. J. Dairy Sci. 98:4785-4799.

SAS Institute Inc. 2002. SAS User's Guide: Statistics. Version 9.1. SAS Institute Inc., Cary, NC.

Shingfield, K. J., M. Bonnet, and N. D. Scollan. 2013. Recent developments in altering the fatty acid composition of ruminant-derived foods. Animal 7:132-162.

Solomon, R., L. E. Chase, D. Ben-Ghedalia, and D. E. Bauman. 2000. The effect of nonstructural carbohydrate and addition of full fat extruded soybeans on the concentration of conjugated linoleic acid in the milk fat of dairy cows. J. Dairy Sci. 83:1322-1329.

Tice, E. M., M. L. Eastridge, and J. L. Firkins. 1993. Raw soybeans and roasted soybeans of different particle sizes. 1. Digestibility and utilization by lactating cows. J. Dairy Sci. 76:224-235.

Tice, E. M., M. L. Eastridge, and J. L. Firkins. 1994. Raw soybeans and roasted soybeans of different particle sizes. 2. Fatty acid utilization by lactating cows. J. Dairy Sci. 77:166-180.

Van Keulen, V., and B. H. Young. 1977. Evaluation of acid-insoluble ash as natural marker in ruminant digestibility studies. J. Anim. Sci. 26:119-135.

Van Soest, P. J., J. B. Robertson, and B. A. Lewis. 1991. Methods for dietary fiber, neutral detergent fiber, and nonstarch polysaccharides in relation to animal nutrition. J. Dairy Sci. 74:3583-3597.

Wilson, R. C., T. R. Overton, and J. H. Clark. 1998. Effects of Yucca shidigera extract and soluble protein on performance of cows and concentrations of urea nitrogen in plasma and milk. J. Dairy Sci. 81:1022-1027.

Wright, C. F., M. A. G. Von Keyserlingk, M. L. Swift, L. J. Fisher, J. A. Shelford, and N. E. Dinn. 2005. Heat- and lignosulfonatetreated canola meal as a source of ruminal undegradable protein for lactating dairy cows. J. Dairy Sci. 88:238-243. 